\title{
PROBIOTIK Bacillus firmus UNTUK PENGENDALIAN PENYAKIT Aeromonas hydrophila PADA BUDIDAYA IKAN LELE DUMBO, Clarias gariepinus
}

\author{
Angela Mariana Lusiastuti*), Tuti Sumiati*), dan Wartono Hadie**) \\ *) Balai Penelitian dan Pengembangan Budidaya Air Tawar \\ Jl. Sempur No. 1, Bogor \\ **) Pusat Penelitian dan Pengembangan Perikanan Budidaya \\ Jl. Ragunan 20, Pasar Minggu, Jakarta Selatan \\ E-mail: Iusiastuti@yahoo.com
}

(Naskah diterima: 5 April 2012; Disetujui publikasi: 12 Juli 2013)

\begin{abstract}
ABSTRAK
Penelitian ini bertujuan untuk mengetahui efektivitas pemberian bakteri probiotik Bacillus firmus terhadap ketahanan benih ikan lele dumbo (Clarias gariepinus) yang diinfeksi Aeromonas hydrophila. Probiotik diberikan melalui media budidaya dengan Rancangan Acak Lengkap (RAL) menggunakan lima perlakuan dan tiga ulangan yang diaplikasikan untuk pengendalian penyakit motile aromonas septicemia (MAS). Perlakuan tersebut adalah A (tanpa penambahan bakteri probiotik B. firmus (sebagai control), B (penambahan bakteri probiotik B. firmus $10^{5} \mathrm{cfu} / \mathrm{mL}$ ), $C$ (penambahan bakteri probiotik $B$. firmus $10^{7} \mathrm{cfu} / \mathrm{mL}$ ), D (penambahan bakteri probiotik $B$. firmus $10^{9} \mathrm{cfu} /$ $\mathrm{mL}$ ), dan $\mathrm{E}$ (penambahan bakteri probiotik $B$. firmus $10^{11} \mathrm{cfu} / \mathrm{mL}$ ). Pengamatan meliputi tingkat sintasan ikan uji setelah diuji tantang dengan $A$. hydrophila, indeks fagositik, diferensial leukosit dan kualitas air. Analisis data tingkat sintasan dilakukan dengan menggunakan uji F dengan taraf signifikansi 5\%. Indeks fagositik, differensial leukosit dan kualitas air dianalisis secara deskriptif. Hasil penelitian menunjukkan bahwa sintasan tertinggi setelah diinfeksi $A$. hydrophila terdapat pada perlakuan $\mathrm{D}\left(10^{9} \mathrm{cfu} /\right.$ $\mathrm{mL}$ ) yaitu $53,33 \%$ dan adanya peningkatan kadar limfosit sebesar $81 \%$ serta aktifitas fagosit sebesar $60 \%$ setelah penambahan bakteri probiotik B. firmus. Sementara hasil terendah terdapat pada perlakuan A (kontrol) (tanpa penambahan bakteri probiotik) sebesar $8,33 \%$, aktifitas fagosit sebesar $60 \%$ setelah pemeliharaan ikan uji selama 14 hari.
\end{abstract}

KATA KUNCI: Bacillus firmus, Aeromonas hydrophila, lele dumbo

ABSTRACT: Probiotic Bacillus firmus for aeromoniasis disease control in Clarias gariepinus farming. By: Angela Mariana Lusiastuti, Tuti Sumiati, and Wartono Hadie

This study aims to determine the efectiveness of probiotic Bacillus firmus against Aeromonas hydrophila in catfish (Clarias gariepinus). Probiotic used in this study through cultivation media with Completely Randomized Design with five treatments and three replications. The treatment is $A$ (without addition of probiotic bacteria $\boldsymbol{B}$. firmus) as control, B (addition of probiotic bacteria B. firmus $10^{5} \mathrm{cfu} / \mathrm{mL}$ ), $C$ (the addition of probiotic bacteria B. firmus $10^{7} \mathrm{cfu} / \mathrm{mL}$ ), $D$ (the addition of probiotic bacteria B. firmus $10^{9} \mathrm{cfu} / \mathrm{mL}$ ), and $E$ (the addition of probiotic bacteria B. firmus $10^{11}$ $c f u / m L)$. The observation was done on survival rates during challenge test, phagocytic 
index, leucocyte differential and water quality. Data analysis was performed with the survival rate using the $F$ test with a level of 5\%. Phagocytic index, leucocyte differential and the quality of water are analysis in descriptive. The results showed that the highest survival after infected $\boldsymbol{A}$. hydrophila present in treatment $D\left(10^{9} \mathrm{cfu} / \mathrm{mL}\right)$ of $53.33 \%$ and the presence of elevated levels of $81 \%$ lymphocytes and phagocytic activity by $60 \%$ after the addition of probiotic bacteria B. firmus. While the lowest are on treatment A (without addition of probiotic bacteria) of $8.33 \%$, phagocyte activity by $60 \%$ after fish maintenance for 14 days.

\section{KEYWORDS: Bacillus firmus, Aeromonas hydrophila, catfish}

\section{PENDAHULUAN}

Ikan lele dumbo (Clarias gariepinus) merupakan jenis ikan air tawar yang memiliki pertumbuhan yang sangat cepat, mudah dipelihara, tahan terhadap kondisi air yang buruk, memiliki nilai gizi dan nilai ekonomis yang cukup tinggi (Bachtiar, 2006). Hal ini merupakan keunggulan yang tinggi bagi budidaya ikan lele.

Menurut Irianto (2005), definisi penyakit sebagai suatu keadaan fisik, morfologi atau fungsi yang mengalami perubahan dari kondisi normal yang disebabkan oleh faktor internal dan faktor eksternal. Faktor internal meliputi keturunan (genetik), umur dan imunodefisiensi, sedangkan faktor eksternal meliputi lingkungan, nutrisi, dan patogen. Penyakit yang menyerang ikan secara umum dikelompokkan menjadi dua yaitu penyakit infeksius dan non infeksius. Jenis penyakit non-infeksius disebabkan oleh lingkungan, makanan, dan genetik. Sementara, jenis penyakit infeksius terdiri dari penyakit yang disebabkan oleh parasit, jamur, bakteri, dan virus. Bakteri patogen pada ikan lele antara lain adalah Aeromonas hydrophila, sebagai penyebab penyakit Motile Aeromonas Septicemia (MAS) (Taukhid et al., 2006).

Di Indonesia, infeksi $A$. hydrophila keberadaannya setelah terjadi wabah penyakit bercak merah pada ikan air tawar di Jawa Barat pada akhir tahun 1980 dan awal tahun 1981 (Supriyadi \& Taufik, 1981). A. hydrophila merupakan bakteri paling ganas dan menyerang berbagai jenis ikan air tawar dari segala umur dan ukuran.

Berbagai cara telah berhasil dilakukan untuk mengendalikan infeksi bakterial pada ikan baik secara kuratif (pengobatan) maupun preventif (pencegahan). Penggunaan antibiotik dan bahan kimia sering dipakai untuk menanggulangi infeksi bakterial, Namun, penggunaan zat kimia yang kurang tepat dapat menimbulkan resistensi pada ikan dan juga dapat membahayakan manusia sebagai konsumen. Saat ini telah banyak dikembangkan metode lain yang lebih aman dan efektif yaitu salah satunya adalah dengan penggunaan probiotik. Probiotik adalah mikroba hidup yang mampu memberikan keuntungan bagi inang yakni dengan memodifikasi komunitas mikroba atau berasosiasi dengan inang, memperbaiki nilai nutrisi dan pemanfaatan pakan, meningkatkan respon inang terhadap penyakit dan memperbaiki kualitas lingkungan (Verschuere et al., 2000).

Berdasarkan alasan tersebut maka aplikasi probiotik tidak hanya berfungsi sebagai bioremediasi untuk memperbaiki kualitas lingkungan atau meningkatkan nilai nutrisi pakan, melainkan dapat pula berfungsi sebagai agen biokontrol untuk mengurangi serangan penyakit (Widanarni et al., 2008). Probiotik tidak terakumulasi dalam tubuh ikan dan tidak menyebabkan resistensi organisme patogen seperti pada antibiotik (Guo et al., 2009).

Penelitian mengenai penggunaan probiotik Bacillus sp. sudah banyak dilakukan sebelumnya. Beberapa jenis bakteri seperti $B$. coagulans, $B$. firmus, dan B. laterosporus berpotensi dalam menghambat pertumbuhan bakteri patogen Aeromonas spp. pada kultur larva ikan mas (Cyprinus carpio) (Adriani, 2006). B. firmus merupakan bakteri probiotik yang diisolasi dari kolam pemeliharaan budidaya ikan nila. B. firmus ini bekerja dengan cara berkompetisi dengan bakteri patogen baik di dalam memperoleh sumber energi pada media budidaya dan berkompetisi untuk memperoleh tempat perlekatan (adhesion site) di dalam saluran cerna sehingga mencegah kolonisasi patogen A. hydrophila (Lusiastuti \& Taukhid, 2012). Kemampuan untuk melekat atau menempel pada mucus dan permukaan dinding saluran cerna merupakan kriteria utama supaya bakteri probiotik dapat tetap 
hidup di dalam saluran cerna. Di samping itu $B$. firmus mampu memproduksi subtansi penghambat yang dapat membunuh patogen A. hydrophila (Lusiastuti \& Taukhid, 2012). Short et al. (1999) mengemukakan bahwa terdapat kriteria yang perlu dipertimbangkan untuk mendapatkan probiotik dengan pengaruh positif yang optimal bagi inangnya yaitu memiliki jumlah sel hidup dengan kepadatan 107-109 CFU/ml. Maulana (2010) menunjukkan bahwa penambahan bakteri probiotik (Bacillus sp.) pada media pemeliharaan benih patin hibrid pasupati dengan pemberian $0,0015 \mathrm{ml} / \mathrm{L}$ kepadatan $10^{9}$ $\mathrm{CFU} / \mathrm{ml}$ dan frekuensi pemberian tiga kali sehari memberikan nilai sintasan sebesar $88,97 \%$. Berdasarkan hasil penelitian Peranginangin (2007) menunjukkan bahwa penggunaan probiotik $B$. firmus dengan dosis $10^{9} \mathrm{CFU} / \mathrm{mL} \quad(O D=0,5)$ pada media pemeliharaan dapat meningkatkan tingkat sintasan larva ikan patin umur 36 jam sebesar $47,8 \%$. Namun, sejauh ini belum ada informasi mengenai dosis probiotik tersebut yang efektif dan dapat meningkatkan ketahanan pada benih ikan air tawar. Penelitian ini bertujuan untuk mengetahui kualitas dan dosis yang tepat dari probiotik $B$. firmus yang diaplikasikan lewat media budidaya terhadap ketahanan benih lele dumbo (Clarias gariepinus) yang diinfeksi $A$. hydrophila. Hasil penelitian ini diharapkan dapat memberikan informasi yang tepat mengenai kegunaan bakteri probiotik $B$. firmus untuk mengatasi serangan bakteri $A$. hydrophila pada pembenihan dan pembesaran lele dumbo (Clarias gariepinus).

\section{BAHAN DAN METODE}

\section{Persiapan Ikan Uji}

Ikan uji yang digunakan adalah adalah lele dumbo sebanyak 800 ekor yang berasal dari kelompok tani perikanan Parung, Bogor, Jawa Barat. Ukuran bobot benih ikan lele dumbo berkisar 10-12 gram dengan panjang antara 8$12 \mathrm{~cm}$. Benih ikan yang diperoleh berasal dari satu induk agar tingkat keragaman /sifat individu relatif sama. Benih ikan diaklimatisasi selama satu minggu. Selama masa tersebut, ikan uji diberi pakan berupa pelet dengan frekuensi pemberian pakan tiga kali sehari pada pagi, siang dan sore hari. Padat penebaran 10-20 ekor per akuarium. Sebelum ikan uji dimasukkan ke dalam akuarium, terlebih dahulu ditimbang bobotnya untuk menentukan dosis pakan yang diberikan.

Pemeliharaan ikan uji dilaksanakan selama 14 hari. Selama masa pemeliharaan tersebut, media budidaya ikan uji diberi bakteri probiotik dengan frekuensi 3 hari sekali sesuai perlakuan. Pakan diberikan 3\% dari bobot biomassa/hari yang dibagi ke dalam 3 kali pemberian yaitu pada pagi, siang dan sore hari. Selama penelitian berlangsung tidak ada penggantian dan penyiponan air. Pengujian kualitas air dilakukan pada awal pemeliharaan (hari ke-1), hari ke-7 dan hari ke-14 pemeliharaan.

Metode yang digunakan dalam penelitian ini adalah Metode Eksperimen dengan Rancangan Acak Lengkap yang menguji bakteri probiotik (B. firmus) dengan 5 perlakuan dan 3 pengulangan, yaitu:

$A=$ Tanpa penambahan probiotik

$\mathrm{B}=$ Penambahan probiotik (B. firmus) kepadatan $10^{5} \mathrm{cfu} / \mathrm{mL}$

$\mathrm{C}=$ Penambahan probiotik (B. firmus) kepadatan $10^{7} \mathrm{cfu} / \mathrm{mL}$

$\mathrm{D}=$ Penambahan probiotik (B. firmus) kepadatan $10^{9} \mathrm{cfu} / \mathrm{mL}$

$\mathrm{E}=$ Penambahan probiotik (B. firmus) kepadatan $10^{11} \mathrm{cfu} / \mathrm{mL}$

\section{Pengukuran Konsentrasi Bakteri Probiotik}

Pengukuran konsentrasi bakteri dilakukan untuk mengetahui kepadatan bakteri per $\mathrm{mL}$ sehingga dapat diketahui berapa banyak bakteri yang harus diambil untuk setiap dosis yang diberikan. Pengukuran konsentrasi bakteri dilakukan menggunakan spektrofotemeter dengan panjang gelombang $520 \mathrm{~nm}$. Penyiapan kultur probiotik berdasarkan Optical Density larutan probiotik pada panjang gelombang $520 \mathrm{~nm}$ yaitu 0,789 yang setara dengan Total Plate Count 5,5 x $10^{15} \mathrm{cfu} / \mathrm{mL}$.

\section{Uji Tantang:}

Setelah dilakukan masa pemeliharaan selama 14 hari, kemudian dilakukan uji tantang terhadap benih ikan. Infeksi buatan dilakukan melalui penyuntikan secara intra peritoneal (IP) pada benih ikan lele dumbo (Clarias gariepinus) dengan konsentrasi larutan bakteri $A$. hydrophila $1,0 \times 10^{8} \mathrm{CFU} / \mathrm{mL}$ yang telah ditingkatkan virulensinya dengan kaidah 
Koch's Postulat. Pengamatan dilakukan terhadap gejala klinis dan sintasan benih ikan hingga hari ke-14 setelah proses infeksi. Pengamatan dihentikan jika ikan uji mati secara keseluruhan meskipun belum mencapai 14 hari. Pada masa uji tantang tidak dilakukan penyiponan dan penggantian air. Pemberian pakan dilakukan sama dengan pada masa pemeliharaan ikan sebelum uji tantang.

Gejala klinis yang diamati adalah kerusakan permukaan tubuh dan tingkah laku ikan yang mencakup respon terhadap pakan. Pengamatan tersebut dilakukan saat dan setelah uji tantang sampai akhir penelitian.

\section{Diferensial Leukosit}

Pengamatan diferensial leukosit dilakukan sebanyak tiga kali sampling yaitu sebelum pemberian probiotik, pasca pemberian probiotik dan pada saat uji tantang pada minggu pertama. Pengamatan ini dilakukan untuk mengetahui perubahan jumlah total leukosit sehingga dapat mengetahui respon kekebalan tubuh ikan saat pemberian bakteri probiotik dan saat uji tantang. Pengamatan dilakukan terhadap sampel ikan sebanyak satu ekor yang diambil dari setiap perlakuan dan setiap ulangan. Sel-sel darah putih yang dihitung pada penelitian ini adalah sel-sel darah limfosit, monosit, dan neutrofil. Dari 100 sel darah putih tersebut, dihitung berapa jumlah sel limfosit, monosit, dan neutrofil. Secara matematika, perhitungan deferensial leukosit menurut Kent \& Thunet (1987) sebagai berikut :

$$
\begin{aligned}
& \text { Persentase limfosit }=\frac{\mathrm{L}}{100} \times 100 \% \\
& \text { Persentase monosit }=\frac{\mathrm{M}}{100} \times 100 \% \\
& \text { Persentase neutrofil }=\frac{\mathrm{N}}{100} \times 100 \%
\end{aligned}
$$

Keterangan:

$\mathrm{L}=$ Jumlah del darah putih limfosit

$\mathrm{M}=$ Jumlah sel darah putih monosit

$\mathrm{N}=$ Jumlah sel darah putih neutrofil

$\mathrm{L}+\mathrm{M}+\mathrm{N}=100$ sel

$\mathrm{L} \%+\mathrm{M} \%+\mathrm{N} \%=100 \%$

\section{Indeks Fagositosis}

Pengamatan Indeks Fagositosis dilakukan sebanyak tiga kali yaitu sebelum pemberian probiotik, saat pemberian probiotik dan pada saat uji tantang minggu ke-1. Pengamatan pada saat pemberian perlakuan $B$. firmus untuk mengetahui kemampuan sel-sel fagosit dalam melakukan mekanisme fagositosis, dan pengamatan pada saat uji tantang untuk mengetahui kemampuan leukosit dalam melakukan mekanisme fagositosis saat diinjeksi $A$. hydrophila. Indeks fagositik dihitung berdasarkan persen (\%) leukosit yang memfagosit pathogen dibandingkan dengan leukosit yang tidak memfagosit.

\section{Tingkat Sintasan Ikan Uji}

Tingkat sintasan diamati pada masa uji tantang selama 14 hari. Pengamatan parameter tersebut dilakukan setiap hari. Perhitungan parameter tingkat sintasan menurut Effendie (1997), adalah:

$$
\mathrm{SR}=\frac{\mathrm{Nt}}{\mathrm{No}} \times 100 \%
$$

di mana:

$\mathrm{SR}=$ Survival Rate $(\%)$

$N t$ = Jumlah benih nila yang hidup pada akhir pengamatan

$N o=$ Jumlah benih nila pada awal pengamatan

\section{Analisis Data}

Pengaruh perlakuan terhadap tingkat sintasan pada ikan uji dianalisis dengan analisis sidik ragam dengan uji F, apabila terdapat perbedaan nyata antar perlakuan dianalisis dengan uji jarak Duncan dengan taraf 5 \% (Gasperz, 1991) dan untuk mengetahui hubungan masing-masing perlakuan dengan sintasan dianalisis dengan analisis regresi. Adapun hasil pengamatan gejala klinis, diferensial leukosit, indeks fagositosis, dan kualitas air dianalisis secara deskriptif.

\section{HASIL DAN BAHASAN}

\section{Gejala Klinis Benih Lele Dumbo Setelah Diuji Tantang}

Gejala yang diamati akibat ada atau tidaknya serangan Aeromoniasis adalah gerakan renang normal, gerakan renang tidak seimbang, pernafasan ikan tidak normal atau gasping dan timbul borok/bercak merah pada kulit.

Hasil pengamatan terhadap gejala klinis benih lele dumbo (C. gariepinus) setelah diuji tantang A. hydrophila memperlihatkan bahwa 
gejala klinis awal muncul setelah 7 jam setelah infeksi, ditandai dengan gerakan renang yang tidak seimbang dan nafsu makan menurun. Gejala klinis awal terlihat jelas pada perlakuan $\mathrm{A}(0 \mathrm{cfu} / \mathrm{mL})$ yang tampak lebih parah, perlakuan $\mathrm{B}\left(10^{5} \mathrm{cfu} / \mathrm{mL}\right)$, dan $\mathrm{C}\left(10^{7} \mathrm{cfu} / \mathrm{mL}\right)$ tetapi tidak separah perlakuan $A$. Hal ini menunjukkan bahwa konsentrasi probiotik $10^{5} \mathrm{cfu} / \mathrm{mL}$ dan $10^{7} \mathrm{cfu} / \mathrm{mL}$ belum cukup mampu mengatasi infeksi $A$. hydrophila. Pada perlakuan D ( $10^{9}$ $\mathrm{cfu} / \mathrm{mL})$ dan $\mathrm{E}\left(10^{11} \mathrm{cfu} / \mathrm{mL}\right)$ hanya terlihat gejala klinis ringan pada sebagian kecil ikan uji.

Hal ini sesuai dengan pernyataan Kabata (1985) bahwa nafsu makan berkurang dan tingkah laku yang abnormal termasuk pada tanda-tanda ikan terserang penyakit akibat infeksi $A$. hydrophila. Kerusakan jaringan tubuh pertama kali muncul setelah 36 jam penginfeksian ditandai dengan adanya luka infeksi di daerah bekas injeksi dan terdapat bercak-bercak merah di permukaan tubuh (Gambar 1), Timbulnya luka infeksi di daerah bekas injeksi karena daerah tersebut yang pertama kali kontak dengan bakteri $A$. hydrophila. Hal ini sesuai dengan pernyataan Affandi (2002) dalam Setiaji (2009) bahwa adanya luka pada kulit merupakan jalan masuk utama (port of entry) untuk beberapa infeksi bakteri. Munculnya kerusakan jaringan tubuh terlihat jelas dan lebih parah pada perlakuan $A, B$, dan $C$ dibandingkan pada perlakuan $D$ dan $\mathrm{E}$.

Kerusakan jaringan di seluruh tubuh benih lele dumbo diduga akibat toksin yang dikeluarkan $A$. hydrophila yang terbawa aliran darah keseluruh tubuh. Seperti yang dikemukakan oleh Aoki (1999), toksin yang dikeluarkan $A$. hydrophila menyebar ke seluruh tubuh melalui aliran darah sehingga menyebabkan haemolisis, yaitu lisis atau pecahnya eritrosit sehingga hemoglobin akan keluar dan pecahnya pembuluh darah berakibat adanya warna kemerahan (bercak merah) pada tubuh ikan. Lebih lanjut Angka et al. (2001) menyatakan bahwa dari beberapa gejala klinis ikan uji yang terserang $A$. hydrophila, terjadinya haemolisis kemungkinan sebagai penyebab kematian ikan uji.

Pada hari ke-2 sampai dengan hari ke- 7 setelah diuji tantang, bercak-bercak merah yang terdapat pada benih lele dumbo berubah menjadi borok-borok merah dan tukak yang ditandai kulit dan daging ikan luka terbuka (Gambar 1). Hal ini terlihat jelas pada perlakuan A (tanpa pemberian bakteri probiotik) dibandingkan dengan perlakuan $\mathrm{B}, \mathrm{C}, \mathrm{D}$, dan $\mathrm{E}$ (diberi bakteri probiotik).

Pada hari ke-11 sampai dengan ke-14 setelah infeksi, kondisi benih lele dumbo ( $C$. gariepinus) berangsur-angsur membaik, hal ini terlihat dari respon makan ikan dan pergerakan renang ikan yang kembali normal. Borok-borok yang terdapat pada benih lele dumbo pun mulai sembuh, terlihat pada luka yang mulai menutup. Hal ini terlihat dengan jelas pada perlakuan $\mathrm{A}, \mathrm{B}$, dan $\mathrm{C}$ yang sebagian ikannya terdapat gejala klinis terserang $A$. hydrophila sedangkan pada perlakuan $\mathrm{D}$ dan E secara keseluruhan tidak terlihat lagi adanya indikasi ikan terserang A. hydrophila. Terjadinya proses penyembuhan mengindikasikan bahwa penambahan probiotik dapat meningkatkan daya tahan tubuh dan menghambat serangan bakteri $A$. hydrophila yang menginfeksi sehingga mempercepat proses penyembuhan dan dapat meningkatkan sintasan benih lele dumbo.

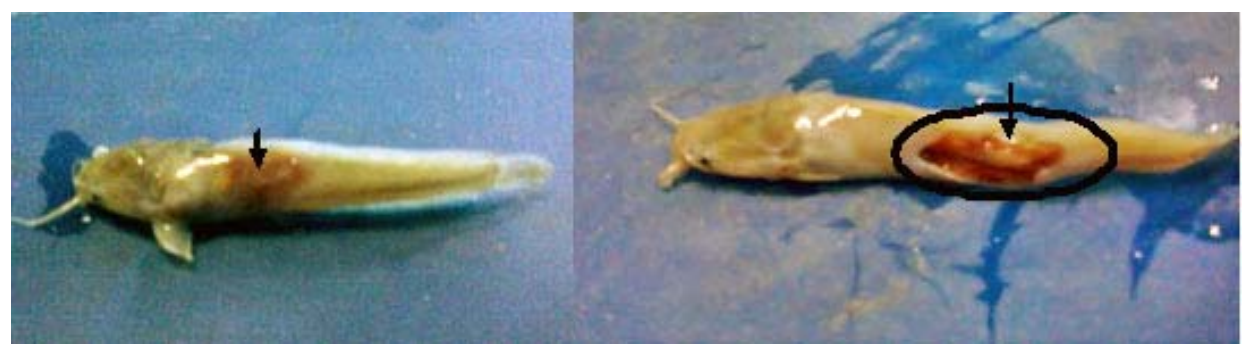

Gambar 1. Luka borok pada daerah bekas injeksi dengan A. hydrophila Figure 1. Ulcer of A. hydrophila in injection area of C. gariepinus 


\section{Sintasan Benih Lele Dumbo Setelah Diuji Tantang}

Berdasarkan hasil analisis ragam memperlihatkan bahwa penambahan probiotik B. firmus pada media pemeliharaan memberikan pengaruh terhadap sintasan benih lele dumbo setelah diuji tantang dengan $A$. hydrophila.

Hasil uji jarak berganda Duncan pada taraf $5 \%$ memperlihatkan bahwa pada perlakuan $\mathrm{A}$ (tanpa penambahan probiotik B. fimus) memberikan sintasan yang berbeda nyata dengan perlakuan $\mathrm{B}\left(10^{5} \mathrm{CFU} / \mathrm{mL}\right), \mathrm{C}\left(10^{7} \mathrm{CFU} /\right.$ $\mathrm{mL}), \mathrm{D}\left(10^{9} \mathrm{CFU} / \mathrm{mL}\right)$, dan $\mathrm{E}\left(10^{11} \mathrm{CFU} / \mathrm{mL}\right)$. Sedangkan perlakuan B dan $C$ tidak berbeda nyata, tetapi berbeda nyata dengan perlakuan D dan E. sedangkan perlakuan D dan E tidak berbeda nyata.

Benih lele dumbo yang dipelihara pada media yang ditambahkan dengan probiotik dengan kepadatan $10^{5} \mathrm{cfu} / \mathrm{mL}$ dan $10^{7} \mathrm{cfu} /$ $\mathrm{mL}$ terjadi peningkatan sintasan. Namun masih lebih rendah dengan perlakuan $\mathrm{D}\left(10^{9} \mathrm{cfu} / \mathrm{mL}\right)$ dan E (10 $11 \mathrm{cfu} / \mathrm{mL})$. Hal ini terjadi karena penambahan dosis bakteri probiotik dengan kepadatan $10^{5} \mathrm{cfu} / \mathrm{mL}$ dan $10^{7} \mathrm{cfu} / \mathrm{mL}$ masih rendah dalam memicu keseimbangan antara aktivasi probiotik dan serangan $A$. hydrophila. Penambahan bakteri probiotik dengan kepadatan $10^{9} \mathrm{cfu} / \mathrm{mL}$ (perlakuan D) dan $10^{11}$ $\mathrm{cfu} / \mathrm{mL}$ (perlakuan E) pada media pemeliharaan memberikan sintasan yang lebih tinggi dibandingkan dengan perlakuan lainnya.

Rendahnya ketahanan benih lele dumbo terhadap serangan $A$. hydrophila pada perlakuan A dilihat dari rendahnya kadar limfosit (Tabel 5) yang merupakan indikator pertahanan tubuh alami. Kadar limfosit benih lele dumbo pada perlakuan B $\left(10^{5} \mathrm{cfu} / \mathrm{ml}\right)$ dan $\mathrm{C}\left(10^{7} \mathrm{cfu} / \mathrm{mL}\right)$ lebih rendah dibandingkan dengan perlakuan $\mathrm{D}\left(10^{9} \mathrm{cfu} / \mathrm{mL}\right)$ dan $\mathrm{E}\left(10^{11}\right.$ $\mathrm{cfu} / \mathrm{mL}$ ) (Tabel 4).

Benih lele dumbo dipelihara pada media yang ditambahkan bakteri probiotik dengan kepadatan $10^{9} \mathrm{cfu} / \mathrm{mL}$ (perlakuan $\mathrm{D}$ ) dan $10^{11}$

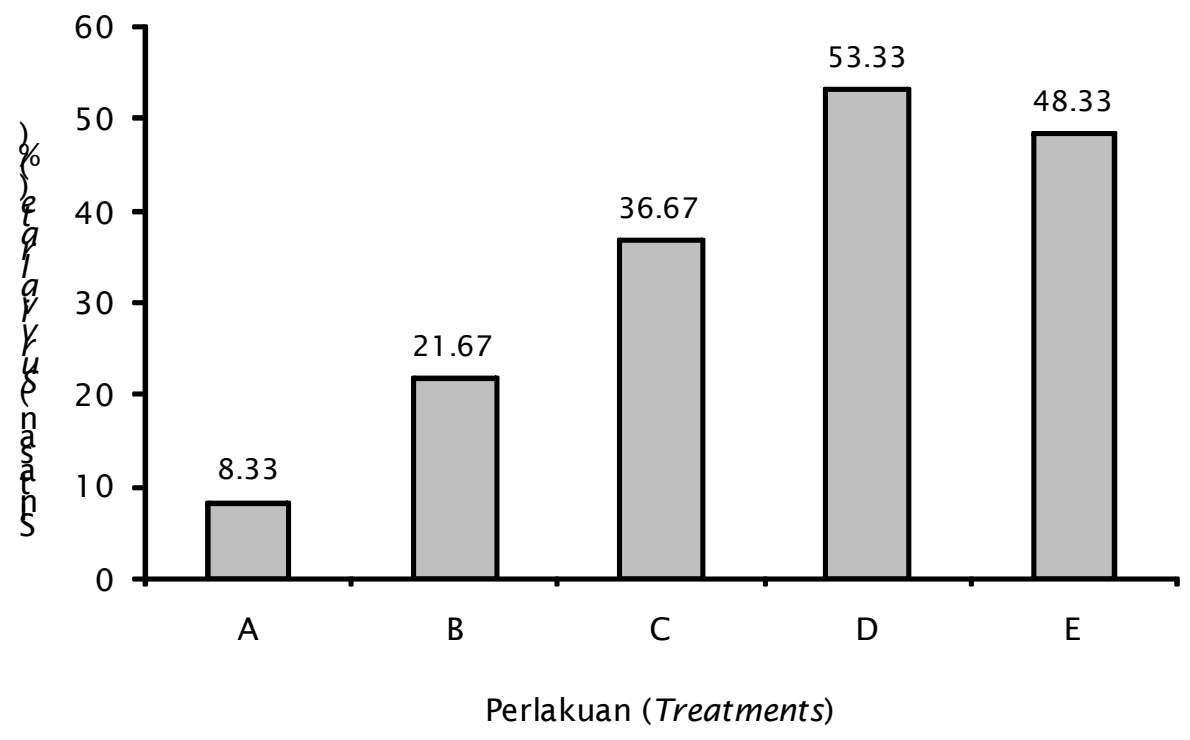

Keterangan: - Huruf kecil yang sama dalam grafik tidak memberikan perbedaan yang nyata menurut uji Duncan

Note:The same small letters in the graph was unsignificantly differences according to Duncan test $-A=0 \mathrm{CFU} / \mathrm{mL}, B=10^{5} \mathrm{CFU} / \mathrm{mL}, C=10^{7} \mathrm{CFU} / \mathrm{mL}, D=10^{9} \mathrm{CFU} / \mathrm{mL}, E=10^{11} \mathrm{CFU} / \mathrm{mL}$

Gambar 2. Sintasan benih C. gariepinus setelah diuji tantang A. hydrophila

Figure 2. The survival rate of fingerling C. gariepinus Challenged with A. hydrophila 
$\mathrm{cfu} / \mathrm{mL}$ (perlakuan E) memberikan respon yang lebih cepat dibandingkan dengan kekuatan serangan A. hydrophila. Peran probiotik adalah berkompetisi di dalam mendapatkan ruang maupun nutrisi pada media budidaya. Probiotik lebih kuat untuk mencegah terjadinya jumlah (quorum) A. hydrophila yang dibutuhkan untuk mengekspresikan faktor-faktor virulensinya, akibatnya $A$. hydrophila tidak dapat tumbuh dan berkembang biak bahkan mengalami kematian. Sebagaimana pernyataan Verschuere et al. (2000) mekanisme kerja probiotik meliputi (1) Produksi senyawa inhibitor, (2) Kompetisi untuk senyawa atau sumber energi yang tersedia (3) perbaikan kualitas air, (4) kontribusi enzim untuk pencernaan. Selain itu dikemukakan oleh Lomakova et al. (2005), bahwa probiotik dapat meningkatkan aktivitas fagosit dan merangsang untuk memproduksi interleukin sehingga memacu antibodi.

Berdasarkan hasil pengamatan terlihat bahwa perlakuan $\mathrm{D}\left(10^{9} \mathrm{cfu} / \mathrm{mL}\right)$ paling tepat dan efektif dalam menanggulangi infeksi $A$. hydrophila dengan nilai sintasan sebesar 53,33\%. Menurut Short et al. (1999) kriteria yang perlu dipertimbangkan untuk mendapatkan probiotik yang efisien dengan pengaruh positif bagi inangnya yaitu dengan jumlah kepadatan berkisar $10^{7} \mathrm{cfu} / \mathrm{mL}-10^{9}$ $\mathrm{cfu} / \mathrm{mL}$.

Pada Gambar 2 terlihat bahwa dosis kepadatan probiotik yang diberikan melalui media pemeliharaan menunjukkan tingkat sintasan benih lele dumbo yang semakin tinggi yaitu $53,33 \%$ sampai dosis $10^{9} \mathrm{cfu} / \mathrm{mL}$, namun pada dosis $10^{11} \mathrm{cfu} / \mathrm{mL}$ terjadi penurunan sintasan yaitu $48,33 \%$. Hal ini diduga karena penambahan probiotik dosis $10^{11} \mathrm{cfu} / \mathrm{mL}$ ke dalam media pemeliharaan akan mengganggu keseimbangan mikroflora dalam media pemeliharaan dan tubuh inangnya,sehingga terjadi kompetisi yang ketat karena jumlah bakteri yang masuk lebih banyak dan mengganggu keseimbangan mikroflora dalam tubuh benih lele dumbo. Hal ini sesuai dengan pernyataan Fuller (1992) bahwa faktor yang mempengaruhi respon inang terhadap probiotik antara lain: komposisi mikroflora, intestinum inang, dosis yang digunakan, umur, dan kualitas probiotik. Nikoskelainen et al. (2001) mengemukakan bahwa penggunaan probiotik dalam dosis tinggi ternyata tidak menjamin perlindungan yang lebih baik terhadap inang.

\section{Diferensial Leukosit}

Pengamatan diferensial leukosit dilakukan dengan menghitung presentase jenis-jenis leukosit yang berperan dalam sistem ketahanan tubuh yaitu limfosit, monosit, dan neutrofil (Gambar 3). Pengamatan ini dilakukan sebanyak tiga kali, yaitu sebelum pemberian probiotik (S0), pasca pemberian probiotik (S1) dan pada saat uji tantang minggu ke-1 (S2). Nilai diferensial leukosit yang diambil merupakan rata-rata proporsi tiga jenis sel leukosit yaitu limfosit, monosit, dan neutrofil.

Pada media yang ditambahkan probiotik, proporsi limfosit dalam darah mengalami peningkatan setelah 14 hari pemberian

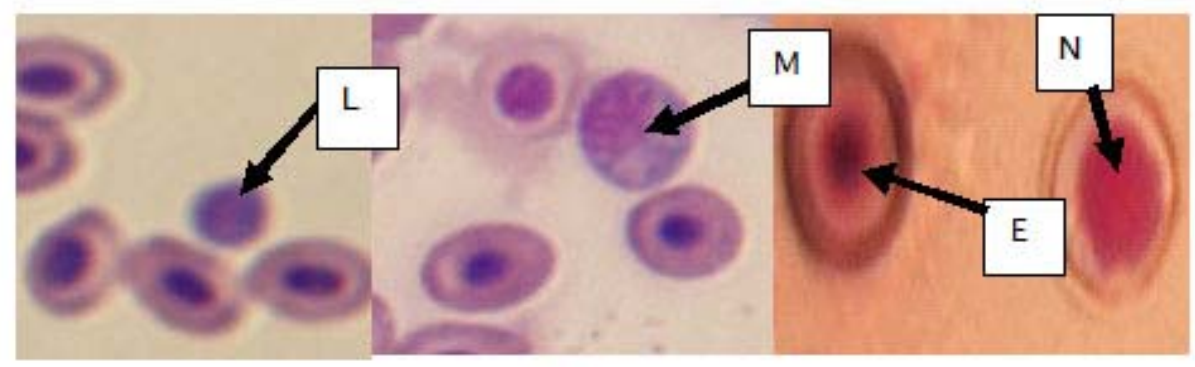

a

b

c

Keterangan: a. limfosit (L), b. monosit (M), c. neutrofil (N), dan eritrosit (E)

Notes: a. Iymphocytes (L), b. monocytes (M), c. neutrophils $(N)$, and erythrocytes $(E)$

Gambar 3. Gambaran sel darah benih C. gariepinus

Figure 3. Pictures of blood cells of C. gariepinus 
probiotik. Perlakuan yang diberi penambahan probiotik menunjukkan kadar limfosit yang lebih tinggi dibandingkan dengan yang tidak ditambahkan probiotik.

Proporsi limfosit dalam darah mengalami penurunan setelah ikan diuji tantang dengan A. hydrophila, baik pada perlakuan yang diberi penambahan probiotik maupun kontrol. Hal ini diduga karena pada saat setelah diinfeksi bakteri terjadi aktivitas perlawanan dari leukosit terhadap A. hydrophila. Hal ini sesuai dengan pendapat Rukyani et al. (1997) bahwa adanya peningkatan intensitas infeksi oleh patogen tertentu akan memicu kebutuhan sel darah putih dan peningkatan kebutuhan tersebut mengakibatkan adanya pengurangan jumlah sel agen penyedia zat kebal tubuh yaitu limfosit.

Presentase monosit semua perlakuan pada masa uji tantang minggu pertama meningkat $15 \%$, sedangkan pada masa pemberian probiotik presentase monosit berkisar 8,5$21,5 \%$. Proporsi monosit dalam leukosit hanya sebesar $0,1 \%$ dan meningkat sekitar 38\% dalam waktu singkat bila terjadi infeksi (Lucky, 1977 dalam Martiani, 2008).

Jumlah neutrofil juga meningkat pada saat uji tantang minggu ke-1. Peningkatan jumlah neutrofil ini berhubungan dengan respon melawan partikel asing yang masuk. Menurut Tizard (1988), neutrofil merupakan garis pertahanan pertama yang bergerak cepat ke arah bahan asing dan menghancurkannya. Menurut Lucky (1977) dalam Martiani (2008), pada saat terjadi infeksi jumlah neutrofil meningkat 6-7\%. Sebagaimana halnya monosit, neutrofil juga merupakan sel berumur pendek sehingga jumlahnya dalam darah berfluktuasi.

\section{Indeks Fagositosis}

Pengamatan indeks fagositosis dilakukan untuk mengetahui respon sel-sel fagosit terhadap adanya antigen (Gambar 4). Antigen yang digunakan adalah bakteri Staphylococcus aureus. Pengamatan dilakukan sebanyak tiga kali yaitu sebelum pemberian probiotik, pasca pemberian probiotik dan masa uji tantang minggu ke-1.

Tabel 1. Presentase diferensial leukosit (limfosit, monosit, dan neutrofil) benih $C$. gariepinus

Table 1. Percentage differential leukocyte (lymphocytes, monocytes, and neutrophils) of C. gariepinus 

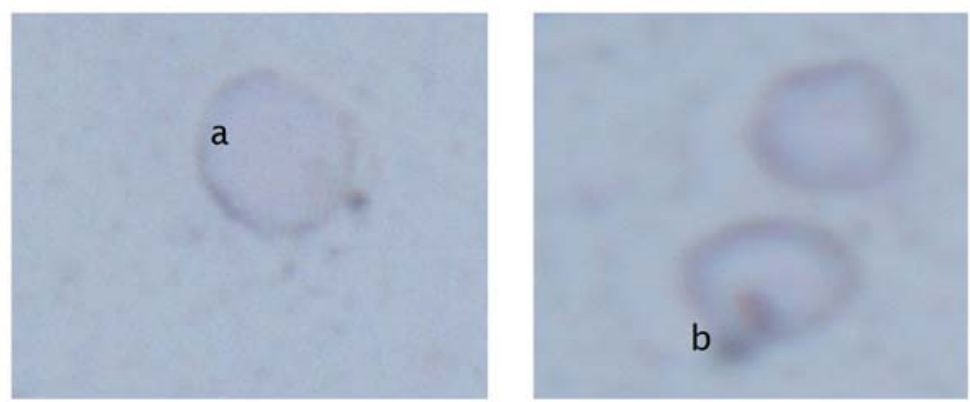

Keterangan: Pembesaran 100x a. Proses penempelan, b. Penelanan antigen,

Description: 100x magnification $a$. The attachment process, $b$. antigen Ingestion

Gambar 4. Fagositosis Antigen oleh Sel Fagosit

Figure 4. Antigen phagocytosis by phagocytic cells

Berdasarkan hasil pengamatan bahwa indeks fagositosis dalam darah ikan uji yang diberi penambahan probiotik pada perlakuan $\mathrm{B}, \mathrm{C}, \mathrm{D}$, dan E lebih tinggi dibandingkan dengan ikan uji yang tidak diberi probiotik (perlakuan A) (Tabel 2). Hal ini disebabkan karena probiotik dapat merangsang kemampuan aktivitas fagosit terhadap antigen sehingga dapat meningkatkan ketahanan tubuh ikan.

Pada perlakuan penambahan probiotik, perlakuan $\mathrm{D}\left(10^{9} \mathrm{cfu} / \mathrm{mL}\right)$ memiliki jumlah sel fagosit yang lebih tinggi dibandingkan perlakuan $B\left(10^{5} \mathrm{cfu} / \mathrm{mL}\right), C\left(10^{7} \mathrm{cfu} / \mathrm{mL}\right)$, dan $\mathrm{E}$ $\left(10^{11} \mathrm{cfu} / \mathrm{mL}\right)$ hal ini diduga disebabkan perbedaan dosis kepadatan probiotik yang dapat merangsang aktivitas fagosit. Adanya perbedaan nilai sel fagosit yang terdapat antara ikan yang diberi probiotik dengan ikan yang tidak diberi probiotik mengindikasikan bahwa ikan uji yang medianya diberikan penambahan probiotik memiliki kemampuan pertahanan non spesifik yang lebih baik.

Pada perlakuan E walaupun nilai indeks fagositosisnya tidak setinggi perlakuan $D$ tetapi dapat menghasilkan tingkat sintasan benih lele dumbo yang lebih tinggi bila dibandingkan perlakuan A, B, dan C terhadap infeksi $A$. hydrophila. Hal ini diduga karena probiotik $B$. firmus masuk ke dalam tubuh (usus dan insang) dan menempel pada kulit

Tabel 2. Rata-rata nilai fagositosis ikan uji

Table 2. Average values of Phagocytosis for test fish

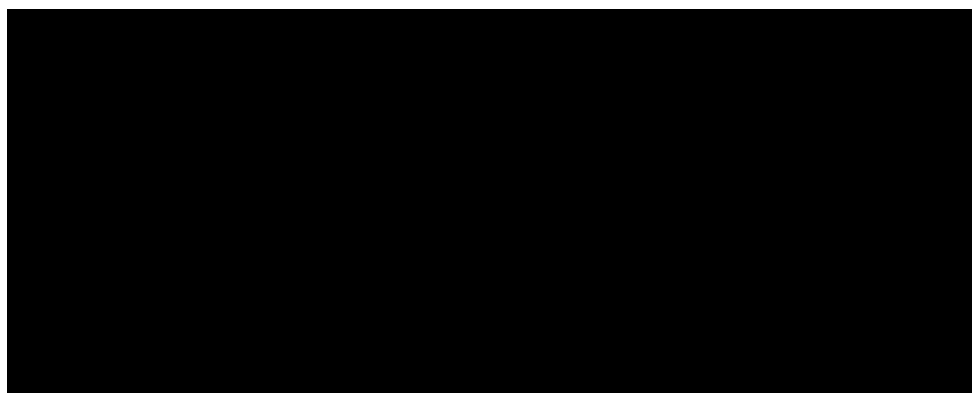

Keterangan (Remarks):

$\mathrm{S} 0=$ sebelum pemberian probiotik./before probiotic treatment

$\mathrm{S} 1$ = setelah pemberian probiotik/after probiotic treatment

S2 = masa uji tantang/ the period of challenge test 
sehingga terjadi kompetisi nutrien atau ruang antara probiotik dengan bakteri patogen. Pada perlakuan $A$, sel fagosit sama sekali tidak bekerja dengan baik sehingga benih lele dumbo mudah sekali terinfeksi $A$. hydrophila, hal ini menyebabkan sintasan benih lele dumbo sangat rendah mencapai 8,33\%.

Tabel 2 juga menunjukkan bahwa indeks fagositosis setelah uji tantang mengalami penurunan baik pada perlakuan maupun kontrol. Penurunan aktivitas fagositik diduga karena adanya infeksi $A$. hydrophila yang menyebabkan beban kerja sel fagositik menjadi lebih besar, sehingga kemampuan memfagositosis bakteri secara in vitro menjadi menurun. Selain itu, penurunan aktivitas fagositik juga diduga karena jumlah sel neutrofil yang aktif mungkin mengalami penurunan. Menurut Tizard (1988), kerja neutrofil cepat tetapi tidak tahan lama, sedangkan fagositik mononuklear bekerjanya lambat sehingga dapat memfagositik berulangulang dan dapat mengolah antigen untuk proses tanggap kebal.

\section{Kualitas Air}

Nilai parameter kualitas air media pemeliharaan selama penelitian berada pada kisaran yang sesuai untuk pemeliharaan benih lele dumbo (Tabel 3). Hal ini menunjukkan bahwa hasil penelitian yang diperoleh disebabkan adanya perbedaan perlakuan dan bukan merupakan pengaruh dari kualitas air.

Selama penelitian dilakukan pengukuran terhadap beberapa parameter kualitas air yaitu, suhu, $\mathrm{pH}, \mathrm{DO}$, dan $\mathrm{NH}_{3}$. Pengamatan kualitas air digunakan sebagai parameter pendukung selama penelitian. Pengamatan diuji pada awal penelitian, tengah dan akhir penelitian. Pemberian probiotik dengan dosis kepadatan yang berbeda ke dalam media pemeliharaan benih lele dumbo selama penelitian memberikan hasil yang bervariasi pada tiap parameter kualitas air.

Berdasarkan hasil pengukuran kualitas air selama penelitian menunjukkan bahwa nilai kualitas air yang diperoleh berada dalam kisaran yang optimum untuk pertumbuhan lele dumbo.

Tabel 3. Kisaran kualitas air media pemeliharaan air selama penelitian

Table 3. Range of water quality value in cultured tanks during experiment

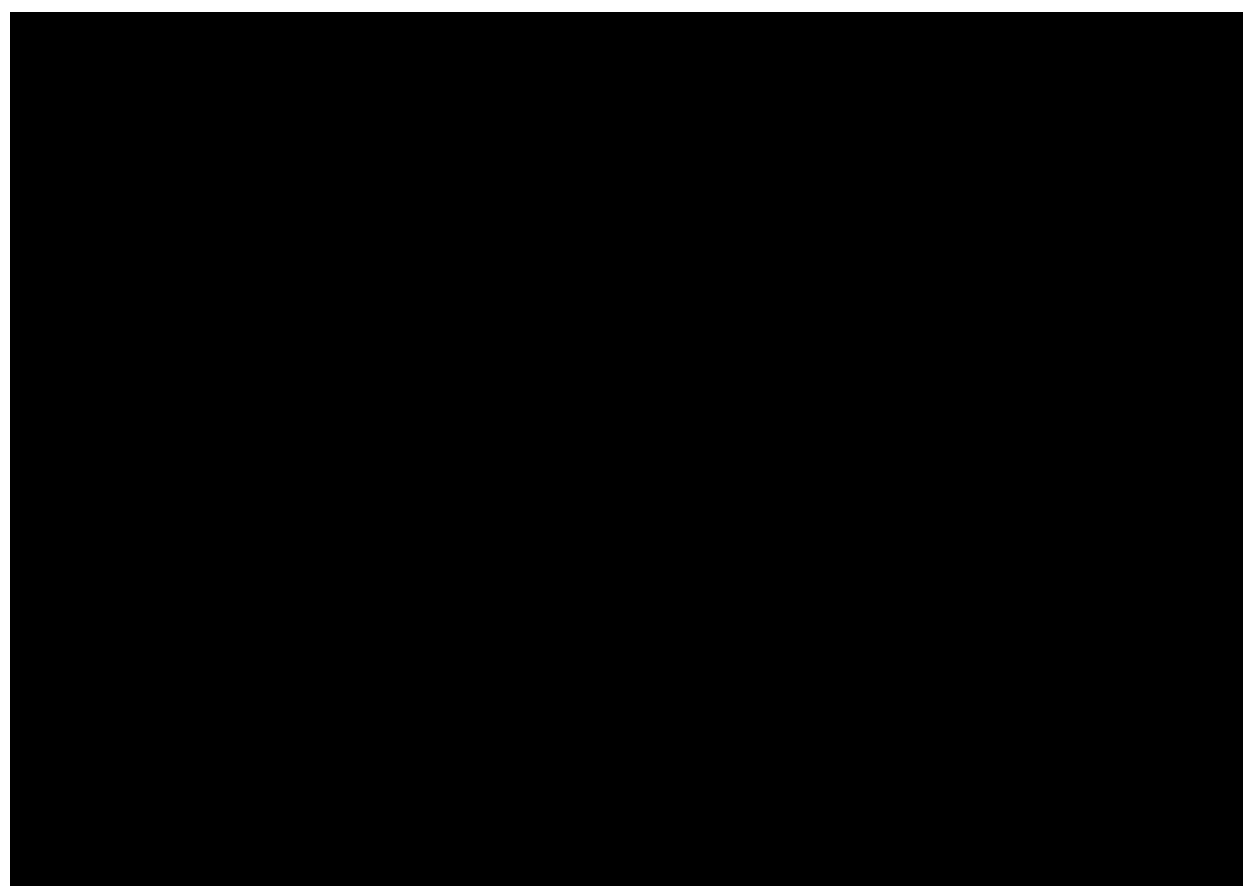


Berdasarkan hasil pengukuran kualitas air (suhu, pH, DO, dan amonia) memperlihatkan bahwa penambahan bakteri probiotik Bacillus firmus dapat mempertahankan kualitas air media pemeliharaan benih lele dumbo (Clarias gariepinus). Dengan demikian, dapat dikemukakan bahwa kualitas airnya masih dalam batas toleransi untuk budidaya lele dumbo sehingga kematian benih lele dumbo bukan disebabkan oleh kualitas air tetapi oleh aktivitas A. hydrophila.

\section{KESIMPULAN DAN SARAN}

\section{Kesimpulan}

Berdasarkan data hasil penelitian dapat diambil kesimpulan bahwa pemberian probiotik B. firmus dengan dosis $10^{9} \mathrm{cfu} / \mathrm{mL}$ terbaik dalam meningkatkan ketahanan tubuh benih lele dumbo dengan sintasan tertinggi $(53,33 \%)$ setelah diuji tantang dengan $A$. hydrophila, dan peningkatan kadar limfosit (81\%) dan aktifitas fagosit (60\%) setelah pemberian probiotik.

\section{Saran}

Berdasarkan hasil penelitian maka perlu dilakukan penelitian lanjutan dengan penggunaan probiotik $B$. firmus dengan dosis $10^{9} \mathrm{cfu} / \mathrm{mL}$ yang diaplikasikan di lapangan untuk mencegah infeksi $A$. hydrophila.

\section{DAFTAR ACUAN}

Amri, K. \& Khairuman. 2008. Syarat Hidup lingkungan bagi lele dumbo. Agro Media Pustaka. Jakarta.

Angka, S.L. 2001. Studi karakterisasi dan patologi Aeromonas hydrophila pada ikan lele dumbo (Clarias gariepinus). Makalah Falsafah Sains. Program Pasca Sarjana. Institut Pertanian Bogor.

Aoki. 1999. Motile Aeromons (Aeromonas spp). J. Laboratory of Genetic and Biochemistry, 11:427-435.

Fuller, R. 1992. Probiotic: The Scientific Basic, Chapman and Hall, London.

Gazperz, V. 1991. Metode Perancangan Percobaan untuk Ilmu-ilmu Pertanian, Ilmuilmu Teknik dan Biologi. Armico, Bandung, $472 \mathrm{hlm}$.

Guo, J.J., Liu, K.F., Cheng, S.H., Chang, C., Lay, J.J., Hsu, Y.O., Yang, J.Y., \& Chen, T.Y. 2009. Selection of Probiotic Bacteria For Use In Shrimp Larviculture. Aquaculture Re- search. Blackwell Publishing, 40: 609-618. Irianto, A. 2005. Patologi Ikan Teleostei. Gadjah Mada University Press, Yogyakarta, $256 \mathrm{hlm}$ Lomakova, I., Petraskova, P., Sterzl, I., \& Prokesova, L. 2006. Immunomodulatory Effects of Bacillus firmus on Mouse Peritoneal Cells in Vitro. Folia Microbiologica. Institute of Microbiology Czechoslovak Academy, 51 (3): 243-247.

Lusiastuti, A.M. \& Taukhid. 2012. Seleksi Kandidat Probiotik Anti Aeromonas hydrophila Untuk Pengendalian Penyakit Ikan Air Tawar. J. Ris. Akuakultur, 7(2): 269277.

Maulana, M. 2010. Pengaruh pemberian bakteri probiotik Bacillus sp. pada media pemeliharaan terhadap sintasan dan pertumbuhan benih patin hybrid pasupati. Skripsi. Fakultas Perikanan dan IImu Kelautan Universitas Padjadjaran Jatinangor.

Martiani, I. 2008. Pengaruh Pemberian Vaksin Koi Herpes Virus (KHV) Dari Donor Inang Terhadap Respon Kekebalan Tubuh Ikan Mas (Cyprinus carpio). Skripsi. Jurusan Perikanan Fakultas Perikanan dan IImu Kelautan. Universitas Padjadjaran. Jatinangor, $70 \mathrm{hlm}$.

Nikoskelane, S., Ouwehand, A., Salminen, S., \& Bylund, G. 2001. Protection of Rainbow Trout Onchorhyncus mykiss from furunculosis by Lactobacillus rhamnosus. Aquaculture, 198: 229-236.

Perangin Angin, R. 2006. Isolasi dan penggunaan bakteri potensial probiotik untuk menghambat Aeromonas hyrophila dalam kultur larva ikan patin Pangasius sutchi. Tesis. Departemen Sekolah Ilmu dan Teknologi Hayati. Institut Teknologi Bandung, Bandung.

Prokesova, L., Novotna, V., Mickova, P., \& Stankova, L. 1998. Effect of Bacillus firmus on antibody formation after mucosal and parental immunization in mice. Immunology, 64: 161-166.

Rukyani, A., Silvia, E., Sunarto, A., \& Taukhid. 1997. Peningkatan Respon Kebal NonSpesifik pada Ikan Lele Dumbo (Clarias sp.) dengan Pemberian Imunostimulan (âGlucan). J. Pen. Perik. Indonesia, 3(1):.

Setiaji, A. 2009. Efektivitas ekstrak daun papaya cariya papaya untuk pencegahan dan pengobatan ikan lele dumbo Clarias sp. yang diinfeksi bakteri A. hydrophila. 
Skripsi. Departemen Budidaya Perairan. Institut Pertanian Bogor.

Short, S., Ouwehand, A.C., \& Salminen, S. 1999. Probiotics: mechanism and established effects. Int. dairy Journal, 9: 43-52.

Supriyadi, H. \& Taufik, P. 1981. Identifikasi dan Cara Penanggulangan penyakit Bakterial pada Ikan Lele (Clarias batrachus). Majalah IImiah Perikanan Indonesia. Badan Penelitian dan Pengembangan Pertanian, Bogor, 1(3): 447-454.

Taukhid, H., Supriyadi, \& Asmaeni, N.D. 2006. Pengaruh Penambahan Vitamin C (Ascorbid acid) pada Pakan Komersil terhadap Ketahanan Benih Lele Dumbo (Clarias sp. Burchell) terhadap Infeksi Bakteri $A$. hydrophila Stainer. J. Ris. Akuakultur, 1(2): 204-209.

Tizard, I. 1988. Pengantar Imunologi Veteriner. Ed ke-2. Partodirejo, M. Hardjosworo, S. Penerjemah; Surabaya: Airlangga University Press. Terjemahan dari: An Introduction to Veterinary Immunology.

Verschuere, L., Rombaut, G., Sorgeloos, P., \& Verstraete, W. 2000. Probiotic bacteria as biological control agents in aquaculture. Microbiol Mo Biol. Rev., 64: 655-671.

Widanarni, Elly, Soelityowati, D.T., \& Suwanto, A. 2008. Pemberian bakteri probiotik Vibrio SKT-b pada larva udang windu (Penaeus monodon) melalui pengkayaan Artemia. Jurnal Akuakultur Indonesia, (7): 129 -137. 